DOI:10.1145/3365383

\title{
The Winner-Takes-All Tech Corporation
}

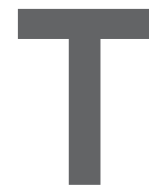

HE FIVE LARgEST U.S. corporations-Alphabet, Amazon, Apple, Facebook, and Microsoft-are all tech companies with combined market capitalization of over four trillion dollars. Tech is often called "Big Tech" these days. Furthermore, a small number of corporations have come to dominate the IT industry, as within each industry segment one corporation often dominates.

The phenomenon whereby corporate dominance seems to be entrenched is often referred to as "winner takes all." In the context of tech, such a phenomenon can be partly explained by two "laws:" Metcalfe's Law asserts that the effect of a communications network is proportional to the square of the number of connected users. This makes Facebook, with over 1.5B daily users, dominant as a social network. Kai-Fu Lee's Virtuous Cycle asserts "More data begets more users and profit, which begets more usage and data." This explains, for example, the dominance of the Google search engine. Metcalfe's Law and the Virtuous Cycle make tech companies into natural monopolies, some claim.

As I argued earlier this year, we need laws and regulations, instead of an ethics outrage, to deal with undesired business models and conduct of tech corporations. What may have been a radical position less than a year ago has become a conventional wisdom now. There are several initiatives to regulate tech; the question now is how rather than if. The biggest regulatory issue on the table is how to deal with overly dominant corporations. In a 2018 book, The Curse of Bigness: Antitrust in the New Gilded Age, legal scholar Tim Wu argues the U.S. must enforce anti-trust laws against such corporations.

Public concerns about overly dominant corporations have been aggravated by what has become a dogma in the U.S. business community over the past generation, which is the Shareholder-Primacy Principle, asserting that shareholders should be assigned a priority relative to all other corporate stakeholders, such as employees, customers, and the like. According to this view, the goal of a corporation is just to generate profits, period! This approach, which has emerged in the 1970s and became dogmatic in the 1980s, has replaced the earlier approach of "corporate responsibility," which made corporations accountable to multiple stakeholders.

Sensing public frustration with the narrow profit motive of U.S. corporations, the Business Roundtable, an association of close to 200 influential U.S. CEOs, recently abandoned its 1997 shareholder-primacy position and declared that "the paramount duty of management and boards of directors is to the corporation's stakeholders." "Society gives each of us a license to operate," declared Ginni Rometty, IBM's CEO. "It's a question of whether society trusts you or not."

But doubts have been expressed about whether corporations can be trusted to regulate themselves, even after their stakeholder-primacy declaration. In a recent book, The Anarchy, historian William Darlymple describes the history of the East India Company, the most successful and most ruthless start-up in history. "Yet if history shows anything," write Darlymple, "it is that in the intricate dance between the power of the state and that of the corpora-
Moshe Y. Vardi

tion, while the latter can be regulated, the corporation will use all the resources in its power to resists."

One of the formidable resources that corporations can marshal is that of corporate personhood, which gives corporations the same legal rights enjoyed by natural persons. In fact, under U.S. law, some essential rights of the $14^{\text {th }}$ Amendment, which addresses equal protection of the laws, belong not only to U.S. citizens but also to corporations. This has farreaching implications. For example, the U.S. Supreme Court ruled in 2010 that corporate funding of independent political broadcasts in candidate elections cannot be limited under the First Amendment because of corporate personhood. This had led to a significant flow of corporate funds into U.S. political campaigns - and money buys influence in politics.

But the $14^{\text {th }}$ Amendment was passed in response to issues related to former slaves following the American Civil War. How it came to be interpreted to grant personhood to corporations is a long and convoluted tale. Many argue that corporations should not have the same rights as natural persons. As IBM CEO Rometty said, society offers corporations a license to operate, so it makes sense for society to define the terms of that license, including rights and responsibilities, the issue of corporate personhood, and the relationship between shareholders and other stakeholders. Perhaps the time has come to formally define the terms of the relationship between society and corporations via a constitutional amendment that explicitly addresses the rights and responsibilities of corporations.

Follow me on Facebook and Twitter.c

Moshe Y. Vardi (vardi@cs.rice.edu) is the Karen Ostrum George Distinguished Service Professor in Computational Engineering and Director of the Ken Kennedy Institute for Information Technology at Rice University, Houston, TX, USA. $\mathrm{He}$ is the former Editor-in-Chief of Communications. 